\title{
Reel Konjonktür Teorisi, Getirdiği Yenilikler ve Diğer Konjonktür Teorileri ile Karşılaştırılması ${ }^{1}$
}

Yüksel BAYRAKTAR ${ }^{2}$

Enes KARAOĞLU ${ }^{3}$

\section{Özet}

Reel Konjonktür teorisi, pratiğe dair çözüm önerileri ve konjonktürel dalgalanmanın yapısal özellikleri hususundaki yeni açıklamaları bakımından konjonktür literatüründe önemli bir role sahiptir. Reel Konjonktür teorisi, iktisadi faaliyetlerde genişleme ve duraklamalara neden olan şoklar, bu şokların yayılması ve bu dalgalanmalar karşısında alınacak politika tedbirleri konularında konjonktür analizinde yeni bir dönem başlatmıştır.

Bu çalışmanın amacı, iktisadi düşünce tarihi serüveni göz önünde bulundurulduğunda varsayımları ve politik önerileri bakımından Klasik-Neoklasik-Yeni Klasik çizginin bir uzantısı olarak değerlendirilebilecek olan Reel Konjonktür teorisinin tarihsel süreçteki gelişimi, bu süreçte hangi araştırmaların etkili olduğu, ve diğer konjonktür teorileri ile benzerlik ve farklılıkları gibi sorulara cevap aramaktır. Reel Konjonktür teorisi savunucuları, konjonktürel dalgalanmanın en önemli nedeninin teknolojik değişim oranındaki tesadüfi dalgalanmalar olduğunu belirtmiştir. Neoklasik yaklaşıma uygun araçların geliştirilmesiyle toplam ekonomik olguyu açıklama metodolojisine sahip Reel Konjonktür teorisine göre, dalgalanmayı oluşturan reel şoklar, yatırımı inşa süreci, tüketimin düzleştirilmesi ve dönemler arası emek ikamesi gibi mekanizmalarla ekonomiye yayılmaktadır.

Anahtar Kelimeler: Reel Konjonktür Teorisi, Teknoloji Şokları, İktisadi Dalgalanmalar

\section{Real Conjecture Theory, Innovations and Comparison with Other Conjuncture Theories}

\section{Abstract}

Real Business Cycle (RBC) theory has a significant role in business-cycle literature in respect to propose solutions and make explanations on structural characteristics of economic fluctuations. The RBC theory has launched a new period in business-cycle analyse about shocks which generates expansions and recessions in economic activities, and propagation of these shocks, and policy determination.

The aim of this study is to discuss on questions such as RBC's historical development process, effective studies, and comparison of other business cycle theories in the context of similarities and differences with RBC theory which can be evaluate with Classical- Neoclassical-New Classical (liberal thought) tradition in the view of assumptions and political agenda. RBC theory claimed that Neoclassical approach is efficient to explain aggragete economic phenomena with developing needed tools. Thus, a new methodology has been generated depending on this approach. As a result of this approach the advocates of RBC theory claimed that the most significant reason of fluctuation is the stochastic changes in technical development. According to RBC the real shocks which generates fluctuations as an impulse mechanism, spread out the aggregate economy via propagation mechanisms such as time to build investment, smoothing consumption and intertemporal substitution of labor.

Keywords: Real Business Cycle theory,Technological Shocks, Economic Fluctuations

\footnotetext{
${ }^{1}$ Bu çalışma, İstanbul Üniversitesi SBE tarafından 2015 yılında kabul edilen Yüksek Lisans Tezinden türetilmiștir.

2 Doç. Dr., İstanbul Üniversitesi, İktisat Fakültesi, İktisat Bölümü, ybayraktar@istanbul.edu.tr

${ }^{3}$ Doktora Öğrencisi, İstanbul Üniversitesi SBE, İktisat Anabilim Dalı,

eneskaraoglu@windowslive.com
} 


\section{Giriş}

Konjonktürel dalgalanma olgusu kriz dönemlerinde ilgi odağı olsa da, iktisadi düşünce okulları arasındaki farklılıkları olușturan konuların önemli bir bölümü konjonktür konusu ile irtibatlı olduğu için her dönem güncelliğini korumayı başarmıştır.

İktisat literatüründe konjonktür olgusunun incelenmesi ile ilgili olarak denklemler sistemi olarak da adlandırılan "ekonometrik yaklaşım" ve "genel denge yaklaşımı" olmak üzere iki yaklaşım bulunmaktadır. Ekonometrik yaklaşıma sahip modellerin enflasyon ile işsizlik arasında ters yönlü ilişki olduğuna dair tahminleri, 1970'li yıllarda yüksek işsizlik ve yüksek enflasyonun birlikte gerçekleşmesiyle başarısızlığa uğramıştır. Denklemler sistemi yaklaşımının süresini doldurmasının bir diğer sebebi ise politikaya göre değişmeyen davranışsal denklemlerin, dinamik çerçevede maksimizasyon varsayımı ile tutarsız olduğunun genel kabul görmesidir. $\mathrm{Bu}$ yaklaşımın bırakılmasının temelinde, dinamik stokastik çerçevede paradigmanın uygulanması ve konjonktürel dalgalanma araştırmaları için gerekli olan neoklasik araçların geliştirilmesi yatmaktadır (Kydland and Prescott, 1991: 161-167). Dolayısıyla iktisadi olayların iktisat okullarının açıklamalarını yönlendirmesi ve konjonktürel dalgalanma açıklamalarının yetersiz kalması sonucu, literatürde yeni bir açıklama biçimi olarak Reel Konjonktür teorisi sahneye çıkmıştır. Reel Konjonktür teorisinin, iktisadi düşünce okulları içerisinde öneminin anlaşılması için, konjonktür teorilerinin "parasal"dan "reel" $\mathrm{e}^{4}$ olan yolculuğunu tarihsel olarak incelemek faydalı olacaktır.

\section{Tarihçe}

1972-1982 y1lları arasında Lucas'1n "parasal sürprize dayalı konjonktür" olarak ifade ettiği ve Neoklasik makro ekonomik yaklaşımla temellendirilen klasik konjonktür tanımlaması, Long ve Plosser'in çalışmalarından sonra yerini "reel denge konjonktür" araştırmalarına bırakmıştır. $\mathrm{Bu}$ araştırmaların başlamasında Yeni Klasik teorisyenlerin parasal sürprize dayalı konjonktürün zayıflıklarına karşı, Neoklasik modelde öngörülemeyen parasal şoklar için kullanılan itki mekanizması yerine, teknolojideki tesadüfi değişimler olarak meydana gelen arz şoklarını öne süren Reel Konjonktür teorisi oluşturulmuştur (Snowdon ve Vane, 2012: 260-261). Reel Konjonktür teorisinin ortaya çıkmasında diğer konjonktür teorilerinin açıklamalarında eksik kalan unsurların rolü de önemlidir. Keynesyen geleneğin mikro temellerden yoksun olması ve 1970'lerdeki stagflasyon olgusunu açıklayamaması, alternatif konjonktür teorisi arayışlarına neden olmuştur.

Monetarist teorinin de 1974-75 durgunluğuna yeterli bir açıklama getirememesi karşısında Reel Konjonktür teorisi, reel GSYİH'nin trendden inişlerinin ve çıkışlarının kaynağı olarak reel şokları işaret ederek bu durgunluğu açıklama girişiminde bulunmuştur (Walsh, 1986: 5-8).

\footnotetext{
${ }^{4}$ Konjonktür teorilerinin sınıflandırılmasında genel olarak kullanılan kıstas, konjonktürün nedenleri ile ilgilidir. Konjonktürü parasal nedenler/şoklar ile açıklayan teoriler, "parasal teori”" olarak; konjonktürün nedeninin reel şoklar olduğunu savunan teoriler ise "reel konjonktür teorileri" olarak adlandırılmaktadır.
} 
Lucas, konjonktür araştırmasını tetikleyen ilk unsurun teknik gelişme olduğunu, yanı sıra gerçekleşen ekonomik olayların ikincil öneme sahip olduğunu belirtmektedir. $\mathrm{Bu}$ tespit Reel Konjonktür Teorisi araştırma programının gelişimiyle doğrulanmıştır. Konjonktür araştırmalarındaki ilerleme, dinamik stokastik modellerin hesaplamalı çözümleri için kullanılan yöntemlerde uzmanlaşmanın artmasıyla gerçekleşmiştir (Williamson, 1996: 1). Konjonktür araştırmasını tetikleyen bir unsur olarak teknik gelişme boyutu, Lucas'ın bir bilgisayar programı aracılığıyla gerçekte pahalıya mal olacak politikaların test edilmesi ve gerçeğe yakın bir model ekonomi oluşturma fikrine dayanmaktadır. Böylelikle Lucas Reel Konjonktür teorisi için bir yol haritası çizmiş olmaktadır.

Lucas makro ekonometrik modellerde kullanılan yapısal parametrelerin uygulanan politika sonuçlarına göre değişeceğini ileri sürmüş, bu parametreleri "derin yapısal parametreler" olarak adlandırarak, tüketici zevkleri, teknoloji, fayda ve üretim parametrelerinin söz konusu modellerde kullanılmasına yol açmıştır. Kydland ve Prescott "Time to Build and Aggregate Fluctuations" çalışmasında bunu daha da ileri götürüp konjonktürel dalgalanmaların açıklanması için Lucas'ın arz fonksiyonu yerine üretim şoklarını kullanmıştır (Savaş, 1997: 1005-1006). Lucas'a göre Kydland ve Prescott'un çalışmaları, makroekonomik modellemeyi yeni bir alan olarak ele aldıklarının göstergesidir. Lucas, konjonktürel dalgalanmayı anlayabilmek için en iyi yolu; "gerçek ekonomilerdeki zaman serisi davranışlarını aynen taklit eden ve tüm bağlantıları oluşturulmuş yapay bir ekonomiyi betimleyen tam teşekküllü bir model kurulması" şeklinde ifade etmiştir. (Snowdon ve Vane, 2012: 261) Lucas'1n, yazılacak bir FORTRAN programiyla gerçek hayatta oldukça yüksek maliyeti olan politikaların, "girdi"nin politika kuralları olduğu, "çıktı"nın ise tahmini politika sonuçları olduğu yapay ekonomi ortamında az maliyetle test edilme olanağı sağlayacağı iddiası, Reel Konjonktür modelleri için bir araştırma gündemi oluşturmuştur (Rebelo, 2005: 218).

Reel Konjonktür teorisinin sahneye çıkmasının nedenlerinden biri de, Lucas'ın iktisadi dalgalanmaları eksik bilgi ile açıklayan teorisine karşılık, Yeni Klasik iktisatçıların sürekli piyasa dengesi içeren bir konjonktür teorisi oluşturma gayesindeki çalışmalarıdır. Kydland, Prescott, Long ve Plosser gibi Reel konjonktür temsilcileri, teorinin olgunlaşmasında belli başlı temellere odaklanmışlardır. $\mathrm{Bu}$ temeller, konjonktüre neden olan stokastik teknolojik süreç (Schumpeter'in görüşünden hareketle), Neoklasik modelin iktisadi dalgalanma açıklaması ve mikro temeller ile uyum şeklinde sıralanabilir (Özer ve Taban, 2006: $63)$.

\section{Reel Konjonktür Teorisinin Temsilcileri}

Reel Konjonktür teorisi, Yeni Klasik okulun bir uzantısı olarak görülse de, temsilcileri itibari ile Yeni Klasik okuldan ayrılmaktadır. Bu okulun en önemli iki temsilcisi, ekonomi politikasının zaman tutarsızlığı ve konjonktürel dalgalanmaların ardındaki itici kuvvetler konusunda dinamik makroekonomiye katkılarından dolayı 2004 yılında Nobel ekonomi ödülünü paylaşan Edward C. Prescott ve Finn Kydland'dır. 
Kydland ve Prescott'un Reel Konjonktür teorisinin kurucu metni kabul edilen "Time To Build And Aggregate Fluctuations" çalışmasında öne çıkan fikirlerden biri, konjonktür olgusunun dinamik genel denge modelleri kullanılarak incelenebileceğidir. Bu modellerde, rekabetçi piyasalarda işlem yapan ve geleceğe yönelik rasyonel beklentilere sahip atomistik ajanlar yer almaktadır. Ayrıca konjonktür ve büyüme teorileri, konjonktürel dalgalanma ile uzun dönem büyüme arasında tutarlılık sağlanması amacıyla entegre edilmiştir (Rebelo, 2005: 218).

Kydland ve Prescott, modelin mikroekonomik çalışmalardan ve ekonominin uzun dönem özelliklerinden belirlenmiş parametrelerle kalibre edilebileceğini ve bu kalibre edilmiş modellerin gerçek verilerle karşılaştırabilecek yapay veriler üretmek için kullanabileceğini ileri sürmüş ve modellerini, Amerikan ekonomisinde gözlemlenen konjonktürel dalgalanmaların temel istatistiki özelliklerini taklit etme potansiyeli açısından değerlendirmişlerdir (Rebelo, 2005: 218-219).

Endüstriyel piyasa ekonomilerinde çıtı ve istihdamdaki büyük konjonktürel dalgalanmalarla aynı anda emeğin marjinal ürününde küçük hareketlerin gözlemlenmesi birçok iktisatçı için şaşırtıcı bir durum olarak nitelendirilmiştir. Ancak Prescott'a göre asıl şaşırtıcı olan çıktı, istihdam ve emeğin marjinal ürününde meydana gelen dalgalanmalar arasındaki şiddet farkı değil, bu dalgalanmalar arasında bir ilişkinin bulunmasıdır (Prescott, 1986: 9). Bu tespit, Reel Konjonktür temsilcileri tarafından başlatılan araştırma programının temel bulgusudur. Bunun sonucunda Reel Konjonktür araştırma grubu rekabetçi dinamik stokastik denge sürecini programlamıştır.

Reel Konjonktür araştırmasının diğer önemli temsilcilerinden olan Robert G. King ve Charles I. Plosser'in ekonomik kurumların yayılma mekanizması olarak ele alınabileceğini ileri sürmesi, modellerinin ayırt edici özelliğini oluşturmaktadır. Finansal endüstrinin çıktısının, yani işlem hizmetlerinin, firmalar ve hanehalkı tarafından kullanılan ara mallar olduğunu ifade etmişlerdir. Böylece çıktıdaki değişme kredi genişlemesini teşvik etmekte ve içsel para ile çıktı arasında pozitif bir korelasyon gerçekleşmektedir. İçsel para fikri, paranın dişsallığı ve paranın konjonktür için birincil sebep olduğu görüşünden farkl1lık arz etmektedir. Bu açıdan Reel Konjonktür teorisi, konjonktürel dalgalanmanın nedenleri ile ilgili tartışmayı canlandırmıştır (Kyun, 1998: 12).

\section{Reel Konjonktür Teorisinin Varsayımları}

İktisat okullarının ortak açıklamaları, tatmin edici teorilere ulaşma yolunda vasıta olarak kullanılan varsayımlara dayanmaktadır. Klasik okul, Neoklasik okul ve Yeni Klasik okul ile Reel Konjonktür teorisi arasındaki benzerlikler, Pareto optimumu, fiyat ve ücretlerin esnekliği ve hükümet müdahalesinin refah azaltıc1 etkisi gibi varsayımlara dayanmaktadır. Bu çalışmada Reel Konjonktür teorisinin temel varsayımları, GSYİH'nın rassal yürüyüş sergilemesi, paranın yansızlığı ve konjonktürel dalgalanmaların temel itki mekanizması kabul edilen teknoloji şokları başlıkları altında incelenecektir. 


\subsection{Rassal Yürüyüş}

İktisadi konjonktürün reel faktörlerle açıklanmasında, ampirik çalışmaların rolü büyüktür. Nelson ve Plosser, kişi başı çıktının, diğer zaman serileri gibi rassal yürüyüş bileşenlerine sahip olduğunu ileri sürmüştür. Yanı sıra Solow'un teknoloji serilerinin de rassal yürüyüsşe sahip olduğu ifade edilmiştir. Buna göre verimliliğin seyri rassal bir yürüyüşü takip etmektedir (Plosser, 1989: 59)

Reel konjonktür teorisyenleri, iktisadi dalgalanmaların temel nedeni olarak ekonominin genelinde meydana gelen arz ve teknoloji şoklarını görmektedir. Buna göre teknoloji şokları ve arz şokları kalıcı olduğu için konjonktürel dalgalanmaların geçici olması için bir neden yoktur. Geleneksel yaklaşıma göre reel GSYİH geçici olarak trendin üstüne çıktığında veya altına indiğinde takip eden dönem içerisinde trende geri dönecektir. Böylelikle GSYİH'daki dalgalanmalar geçici olacaktır. Fakat Nelson ve Plosser'in 1982'deki çalışmaları, reel GSYİH gibi önemli değişkenlerin çok az miktarda geçici dalgalanma içerdiği üzerine temellenmiştir. Bu iddiaya göre, GSYİH'da meydana gelen çoğu değişim kalıcıdır. Bu demektir ki, çıktı bir çeyrek dönemde yüksekse, gelecek çeyrek dönemlerde tekrar düşeceğine dair bir eğilim bulunmamakta ve GSYİH, rassal bir yürüyüş sergilemektedir (Rush, 1987: 25)

Nelson ve Plosser, makroekonomik zaman serilerinde trend ve rassal yürüyüşü ele almışlardır. ABD ekonomisinin verileri göz önünde bulundurulduğunda, bu serilerin trend çizgisine dönme eğilimi göstermeyen, durağan olmayan stokastik süreçler olduğu hipotezinin kabul edilmesi gerektiği ifade edilmiştir. Parasal aksaklıklara odaklanan makroekonomik modellerin çıktılardaki değişimin büyük bölümünü açıklamakta başarısız olacağı ve stokastik değişim nedeniyle reel faktörlerin makroekonomik dalgalanma modelinin esası olduğu vurgulanmıştır (Nelson and Plosser, 1982: 139)

\subsection{Paranın Yansızlığı}

Reel konjonktür teorisine göre, para arzında meydana gelen bir değişim, reel değişkenler üzerinde bir etki meydana getirmemektedir. Bu durumda yapılan iki grup çalışmanın etkisi bulunmaktadır. Birincisi, Nelson ve Plosser'in GSYİH'daki dalgalanmaların büyük kısmının kalıcı olduğunu ortaya koyan çalışmalarıdır. Buna göre para politikası, reel GSYİH üzerinde kalıcı bir etkiye sahip değilse ve GSYİH'da meydana gelen değişimin çoğu kalıcıysa, para politikası reel GSYİH üzerinde önemli bir etkiye sahip değildir (Rush, 1987: 29)

İkincisi ise, GSYİH ile para arzı arasındaki korelasyona odaklanan çalışmalardır. Buna göre para arzı ile reel çıktı arasındaki ilişkin tersine nedensellik şeklinde meydana gelmektedir (Rush, 1987: 30). Yani reel çıktıda meydana gelen değişmeler, para arzını etkilemektedir.

İçsel para arzı olarak adlandırılan bu yaklaşıma göre, parasal büyüme GSYIH'da artışa sebep olmamakta; tersine GSYIH'daki artış para arzında artışa neden olmaktadır. Reel Konjonktür teorisi, parasal toplamlarla reel çıktı arasındaki ilişkiyi, çıktı seviyesi ve işlem hizmetleri talebi arasındaki bağlantı ile açıklamaktadır. Buna göre malların üreticiden tüketiciye transferinde söz konusu 
olan işlem maliyetlerini düşürmek için para talebi oluşmaktadır. Çıktı, konjonktürel dalgalanma boyunca artıp azaldığından, işlem miktarı da artıp azalmaktadır. Böylece para talebi, reel çıktıyla birlikte artıp azalma eğilimi göstermektedir. İlaveten Reel Konjonktür teorisine göre para talebindeki artış veya azalış, para arzında da artış veya azalışı beraberinde getirmektedir. Çıktıdaki artış, hem para talebini hem de faiz oranını artırmaktadır. Artan faiz oranları bankaların ellerinde tuttukları fazla rezervlerin, devlet tahvili veya özel kredilere nazaran daha verimsiz hale gelmesine neden olmaktadır. Böylece bankalar ellerindeki rezervleri azaltmaktadır. Piyasa faiz oranların artışını da para arzı artışı takip etmektedir. Bununla birlikte, para otoritesinin bankacılık sistemine arz ettiği rezervler değişmese de parasal toplamlar ile reel GSYIHH arasında da benzer hareketler meydana gelmektedir (Walsh, 1986: 11-12)

\subsection{Teknoloji Şokları}

Reel Konjonktür teorisi, teknolojik gelişme oranında büyük tesadüfi dalgalanmalar olduğu varsayımı üzerine temellenmiştir. Teknolojik gelişme ile tesadüfi dalgalanmalar arasındaki işleyiş mekanizması şu şekilde açıklanmaktadır. Teknolojik değişimler, üretim fonksiyonuna arz yanlı şoklar şeklinde etki ederek nispi fiyatların değişmesine yol açmaktadır. Bunun sonucunda rasyonel bireylerin emek arzı ve tüketim kararları değişmekte ve nihayet toplam üretim ve istihdamda dalgalanma meydana gelmektedir. Bu açıklama, eski parasal aldanma modellerinin son bulmasına ve Lucas'ın ifadesiyle yapay ekonomi kurulmasına bir cevap niteliği taşımaktadır (Snowdon ve Vane, 2012: 262).

Prescott, 1986 yılında yayınladı̆g1 "Theory Ahead of Business Cycle Measurement" adlı çalışmasında ABD ekonomisi üzerine yaptığı çalışmada toplam faktör verimliliğindeki değişimleri inceleyerek teknolojik dalgalanmalar ile ilgili önemli bulgulara ulaşmıştır. Bu çalışmada verimliliğin sabit ve dışsal olarak değiştiğini varsaymıştır. Prescott, teknoloji şokları ve dönemlerarası ikame varsayıldığında, modelin tahmin ettiği dalgalanmaların ABD ekonomisinde gözlemlenen dalgalanmalarla benzerlik gösterdiğini ifade etmiş̧tir (Prescott, 1986: 9).

\section{4. İtki ve Yayılma Mekanizması}

Reel Konjonktür araştırmasının teorik çerçevesi, konjonktürel dalgalanmanın gerçekleşme süreci ile ilgilidir. Bu bağlamda konjonktür teorisi, itki ve yayılma mekanizmaları ele alınarak incelenmelidir.

Reel Konjonktür teorisi, hangi Neo-klasik büyüme teorisinin konjonktür dalgalanmalarını uzun dönem büyüme trendleriyle birlikte açıklayabileceği üzerine temellenmiştir. $\mathrm{Bu}$ bağlamda, araştırmanın temel sorusu "eğer teknoloji şokları dalgalanmaların tek kaynağı olsaydı, savaş sonrası Amerikan ekonomisinde ne kadar dalgalanma gerçekleşirdi?” şeklinde belirlenmiş̧ir (Kydland and Prescott, 1996: 76-77)

Reel Konjonktür teorisi, teknoloji şoklarını dalgalanmaların birincil nedeni olarak görmektedir. Bu durumda üretim fonksiyonunu değiştiren şoklar karşısında 
emek girdisinin hareketi ve refah analizinde Walrasyen metoda sahip olması önemli rol oynamaktadır.

Hükümet harcamaları veya geçici bir yatırım indirimi (investment tax credit) gibi talep yanlı şokların olması durumunda, tüketim ve boş zaman birlikte hareket eder. Ancak bu şekilde bir talep yanlı izah, tipik bir konjonktürel dalgalanma boyunca tüketim ve boş zamanın birbirinin zıt yönünde hareket ettiğini gösteren verilerle uyumsuzdur. Reel Konjonktür temsilcileri de bireylerin durgunluk döneminde aynı anda neden boş zamanı artırıp tüketimi azalttıklarını açıklamak için, teknolojik gelişme oranında önemli dalgalanmalar olduğunu ifade etmektedir. Buna göre durgunluk döneminde mevcut üretim teknolojisi nispeten elverişsizdir. Emeğin marjinal ürünü, dolayısıyla reel ücret seviyesinin düşük olması, bireylerin tüketimi azaltıp, boş zamanı artırmasına yol açmaktadır. Sonuçta konjonktürel dalgalanma boyunca tüketim, boş zaman, reel ücret gibi değişkenlerin gözlemlenen seyri, teknoloji şoklarının dalgalanmanın en önemli kaynağı olduğu tezi aracılığıyla tutarlı bir teorik yapıya kavuşmaktadır. Teknolojik şokların dalgalanma nedeni olarak öne sürülmesinin diğer bir sebebi de Reel Konjonktür teorisinin Walrasyen metoda sahip olmasıyla ilgilidir. Reel Konjonktür teorisi, dalgalanmaları Walrasyen dengenin değişmesi olarak görmekte, bunun sonucunda meydana gelen dalgalanmaların optimum niteliğe sahip olduğunu ileri sürmektedir. Buna göre bireylerin zevkleri ve teknolojik olanaklar veri iken, istihdam, çıktı ve tüketim gelişmemektedir. Bunun nedeni devletin makro değişkenlere etkisinin "görünmez el" varsayımı nedeniyle etkisiz veya zararlı olmasıdır. Fiyat ve ücretlerin hızlı bir şekilde piyasalarda arz talep dengesini sağlayamadığı kabul edildiğinde, durgunluk döneminde gerçekleşmeyen ticari kazançlar var olmaktadır. Reel Konjonktür teorisinde ise gerçekleşmeyen ticari getiri söz konusu olmadığından refahtaki düşüş, toplumun teknolojik kapasitesinin azalmasından kaynaklanmaktadır (Mankiw, 1989: 82-83)

Reel Konjonktür teorisinde itki mekanizması olarak kabul edilen teknoloji şoklarının ekonomik değiş̧kenler üzerindeki etkisi, yayılma mekanizması olarak kabul edilen tüketimin düzleştirilmesi, yatırımın inşa süresi ve dönemler arası emek ikamesi, mekanizmalarıyla açıklanmaktadır.

\subsubsection{Yatırımı İnşa Süresi}

Yatırımların tamamlanma veya inşa süresi olarak ifade edilen "time to build in investment" kavramı reel konjonktür teorisinden önceki iktisadi dalgalanma teorilerinde de yer almıştır. Genel itibariyle yatırımların tamamlanma süresi kavramı, yatırım projesinin tasarlanması, ihale ve sözleşme evresi, son olarak da inşa evresi şeklinde yatırımların gerçekleşerek üretken sermayeye dönüşme sürecini ifade etmektedir. (Koeva,2000: 4-7).

Kydland ve Prescott'un modellerinde yatırımlar üç çeyrek dönemlik gecikmeyle üretken sermayeye dönüştürülmüştür. Bu durum çıktıdaki içsel (endojen) kalıcılığ 1 artırmakta ve çıktı ile sermaye stoku arasındaki korelasyonu azaltmaktadır. (Söderlind, 1994: 113-114)

Kydland ve Prescott, standart Neoklasik modelde değişiklik yaparak, yeni sermaye malları inşa etmek için birden fazla dönemin gerektiğini ileri sürmüştür. 
Böylelikle Reel Konjonktür teorisinde teknoloji şokuyla başlayan dalgalanmaların, sonrasında ekonomiye nasıl etki ettiğini açıklayan mekanizma geliştirilmiştir. Bu şekilde geliştirilen inşa zamanı teknolojisi, sermayenin gölge fiyatındaki kısa dönemli dalgalanmalarla tutarlıdır. Çünkü kısa dönemde sermaye arzı inelastiktir. Ayrıca bu teknolojiye göre uzun dönemde arz sonsuz elastikiyete sahiptir. Böylece ortalamada yatırım malının nispi fiyatı, yatırım-çıktı oranından bağımsız hareket etmektedir (Kydland and Prescott, 1982: 1348-1349)

\subsubsection{Tüketimin Düzleştirilmesi}

Reel konjonktür modelinde bir şokun yayılma etkisini artıran önemli bir unsur olarak tüketimin düzleştirilmesi yer almaktadır. Tüketimin düzleştirilmesi modelde yer aldığında, yayılma mekanizmasının etkisi büyük ölçüde artmaktadır. Şöyle ki, olumsuz bir şok temsili hanehalkı yatırımlarını daha fazla azaltmak kaydıyla tüketimini artıracaktır. Hanehalkının yatırımları azaltması nedeniyle denge sermaye stokunda daha büyük miktarda azalma gerçekleşir, sermayenin kiralanma maliyeti artar, iş yıkımı (job destruction) yüksek oranlarda kalıcı hale gelir ve çıktı seviyesi azalır (Haan vd., 2000: 483-489).

İktisadi ajanlar zaman içerisinde tüketimlerini düzleştirince çıktıdaki bir artış, kısmen yatırım ve sermaye stokundaki bir artış şeklinde meydana gelmektedir. Yatırımın inşa sürecinde meydana gelen gecikmeler de, gelecekteki yatırımı, dolayısıyla çıktıyı artırarak konjonktürel dalgalanmaların oluşmasında önemli rol oynamaktadır (Stadler, 1994: 1753).

\subsubsection{Dönemler Arası Emek İkamesi}

Şokların ekonomiye etkisini açıklamakta kullanılan yayılma mekanizmalarından bir diğeri dönemler arası emek ikamesidir. Buna göre, bireyler boş zamanı ücretlerdeki değişime göre ikame etmeye eğilimlidir. Ücretler geçici olarak yükseldiğinde emek arzı artarken, ücretler eski seviyesine indiğinde boş zamanı tercih etmektedirler (Stadler, 1994: 1753-1754).

Hükümet harcamalarında bir artış gerçekleştiğinde, üretilen mallar için talep artışı gerçekleşir. Mal piyasasında dengenin gerçekleşmesi için tüketimi ve yatırımı azaltacak şekilde reel faiz oranları artar. Reel faiz oranlarındaki bu artış aynı zamanda bugün çalışmanın gelecekte çalışmaya tercih edilmesine ve bugünkü emek arzının artmasına neden olarak bireylerin boş zamanlarını yeniden tahsis etmelerini sağlar. Emek arzındaki bu artış da denge istihdam ve çıktı seviyesinin yükselmesiyle sonuçlanır (Mankiw, 1989: 81-82).

\section{Temel ve Genişletilmiş Reel Konjonktür Modelleri}

Standart Reel Konjonktür modeli, dalgalanmaların kaynağı olarak üretici ve tüketicilerin teknoloji şokları veya verimlilikte meydana gelen değişmelere verdiği yanıtları göstermektedir. Ücret ve fiyatların tam esnek olduğu ve piyasaların temizlendiği varsayımı altında verimlilikte meydana gelen bir artış, emek talebini artırır ve ekonomi genişleme sürecine girer. Ücretlerin artması ise, 
tüketimin, tasarrufların ve yatırımın artmasına neden olur. Yani olumlu bir teknoloji şoku istihdam, üretim, tüketim ve yatırımın eşanlı davranışını sağlamaktadır (Altuğ, 2009: 8-9).

Temel Reel Konjonktür modelinde, çıktı olarak tek bir mal üreten, sonsuz yaşayan bireylerin oluşturduğu bir ekonomi varsayılmaktadır. Piyasalarda bilgi ve işlem maliyetleri (sürtünme) yoktur. Basitliği sağlamak açısından bu modelde para ve devletin rolü hesaba katılmamıştır. Her bir ajanın tercihleri;

$$
U_{t}=\operatorname{MaxE}_{t}\left[\sum_{J=0}^{\infty} u \beta^{j}\left(c_{t+j}, 1_{t+j}\right) \beta\right], 0<\beta<1
$$

Ekonomide mevcut olan teknoloji, geleneksel bir ölçeğe göre sabit getiri olan üretim fonksiyonu ve sermaye stokunun zaman içerisinde hareket yasasını veren bir eşitlikle tanımlanmıştır. Üretim fonksiyonu;

$$
y_{t}=z_{t} f\left(k_{t}, n_{t}\right)
$$

Yt çıktı, Kt önceki dönemden gelen sermaye, nt emektir. Zt pozitif bir parametredir, üretim fonksiyonunu kaydırır ve toplam faktör verimliliğini değiştirir. zt nin dağılımı zt-1 e bağlıdır. Ayrıca zaman içerisinde sabittir. Sermaye stokunun gelişimi, aşağıdaki denkleme göre gerçekleşir;

$$
k_{t+1}=(1-\delta) k_{t}+i_{t}
$$

$\delta$ Amortisman oranını göstermekte, $1_{t}$ yatırımı göstermektedir. Bir tür malın olduğu modelde, çıktının tüketilmeyen kısmı gelecek dönemin sermaye stoku olur. Çalışma-boş zaman ve tüketim ve yatırıma dair kaynak kısıtları;

$$
\begin{aligned}
& c_{t}=i_{t}+y_{t} \\
& n_{t}+l_{t}=h_{t}
\end{aligned}
$$

bütün ajanlar aynı olduğu için fiyat ve miktar dengesi, ajanın optimizasyon problemiyle çözülebilir. Beklentilerin rasyonel olduğu varsayılmıştır. Böylece ajanın olasılık dağılımına dayanan beklentileri, ekonomik yapıyla ilişkilidir. Bütün hanehalkları aynıdır, ajanlar $\mathrm{z}_{\mathrm{t}}$ nin oluşturduğu olasılık dağılımını ve zt nin o anki değerini bilirler ve bütün piyasalar temizlenir. Böylece, (2) ve (4) denklemlerdeki kisitlara maruz kalan (1) denklemdeki maksimizasyon, piyasa dengesini tanımlayan birinci dereceden koşulları sağlamaktadır.

$$
\begin{aligned}
& u_{1}\left(c_{t}, 1_{t}\right)-\lambda_{t}=0 \\
& u_{2}\left(c_{t}, 1_{t}\right)-\lambda_{t} z_{t} f_{2}\left(k_{t}, n_{t}\right)=0 \\
& -\lambda_{t}+E_{t} \beta \lambda_{t+1}\left[z_{t} f_{1}\left(k_{t}, n_{t}\right)-(1-\delta)\right]=0 \\
& c_{t}+k_{t+1}=z_{t} f(k t, n t)+(1-\delta) k_{t}
\end{aligned}
$$

$\mathrm{U}_{\mathrm{i}}$ ve $\mathrm{f}_{\mathrm{i}}$, i' inci argümanlarına göre $\mathrm{u}(\bullet)$ ve $\mathrm{f}(\bullet)$ nin kısmi türevlerini gösterir ve $\lambda_{t}$ Lagrange çarpanıdır. Yukarıdaki denklemler ekonominin emek, sermaye, tüketim ve $\lambda$ değerlerinin zaman patikalarını belirlemektedir.

Fayda ve üretim fonksiyonları tanımlandıktan sonra, üç seçenek değişkeninin, $c_{t}, k_{t}, n_{t}$ zaman patikaları çözülebilir. Kesin bir çözüm elde etmek için, sermayenin tek bir dönem içinde tamamen amortismana uğradığı, faydanın 
logaritmik doğrusal (log-linear) şekilde ve üretim fonksiyonunun Cobb-douglas olduğu varsayıldı ̆̆ında;

$$
\begin{aligned}
& \mathrm{u}(\bullet)=\theta \log \mathrm{c}_{\mathrm{t}}+(1-\theta) \log \left(1-\mathrm{n}_{\mathrm{t}}\right) \\
& \mathrm{Z}_{\mathrm{f}} \mathrm{f}(\bullet)=\mathrm{z}_{\mathrm{t}} n_{t}^{a} k_{t}^{1-\alpha}
\end{aligned}
$$

$\mathrm{Bu}$ varsayımlar altında, bir ücret değişiminin gelir ve ikame etkileri birbirini geçersiz kılar. Böylece emek sabit kalır. Belirlenmemiş katsayılar yöntemi kullanıldığında, tüketim ve sermaye stokunun değerleri şöyle çözülür,

$$
\begin{aligned}
& \mathrm{c}_{\mathrm{t}}=[1-(1-\alpha) \beta] \mathrm{z}_{\mathrm{t}} n_{t}^{a} k_{t}^{1-\alpha} \\
& \left.\mathrm{k}_{\mathrm{t}+1}=(1-\alpha) \beta\right] \mathrm{z}_{\mathrm{t}} n_{t}^{a} k_{t}^{1-\alpha}
\end{aligned}
$$

$\mathrm{Bu}$ zaman patikaları, birinci dereceden koşulları sağlamakta, ve modelde iktisadi ajanlar için optimal karar gösterilmektedir. (11) ve (12) denklemlere göre dönemlerarası ikamenin işleyişi şu şekildedir; $Z_{t}$ nin uzun dönem değeri etrafındaki geçici değişim, mevcut tüketimi değiştirmekle birlikte, şokun etkisini yayan sermaye stokundaki değişimi de göstermektedir. Böylelikle verimlilikteki bir artış, birkaç dönem için tüketim ve sermaye stokunu artırmakta, bunun sonucunda model konjonktürel bir seyir sergilemektedir (Stadler, 1994: 1754-1755).

İktisatç1ların Reel Konjonktür teorisine ilgisi, mikro temellerin tam olarak tanımlanmış olması ve Neoklasik büyüme modeli ile arasındaki bağlantı nedeniyle oluşmuştur. Temel Reel Konjonktür modeli, emek-boş zaman tercihinin de dâhil edildiği standart Neoklasik büyüme modelinin yapısına sahiptir. Modelde faydasını tüketim ve boş zaman tercihine bağlı olarak sağlayan temsili tüketici yer almakta, bununla birlikte emek ve sermayenin kullanıldığ 1 tek tip mal üretmek için ölçeğe göre sabit getirinin olduğu üretim teknolojisi varsayılmaktadır. Modelin geçerli olduğu ekonomik çevrede, bütün piyasalarda tam rekabetin olduğu, üretim faktörlerinin tümünün istihdam edildiği ve fiyatların piyasaları temizleyecek biçimde hızlı bir şekilde ayarlandığı varsayılmaktadır. Standart Reel Konjonktür modeli, hanehalkının yalnızca piyasalarda üretilen malları tükettiğini varsaymaktadır. Devlete ve dişa açık bir ekonomiye yer vermeyen bu model eleştirilmiştir. Daha sonra Reel Konjonktür yaklaşımı, devleti ve dış ticareti içerecek şekilde genişletilmiştir (Altuğ, 2009: 34)

Buraya kadarki analizlerin çoğunda teknolojik şokların etkisi üzerine odaklanıldı. Bununla birlikte tüm şoklar, arz, çalışma-boş zaman tercihi gibi unsurları etkileyerek mal talebini etkileyebilir. $\mathrm{Bu}$ durum talep şoklarının oluşturduğu Reel Konjonktür modeline öncülük edebilir. Ayrıca modele hükümette dâhil edildiğinde talep şoklarının kaynağı da hesaba katılmış olur. Dolayısıyla Reel Konjonktür modelinin doğası, analizleri teknoloji veya arzdaki değişme ile sınırlandırmaya müsaade etmemektedir (Plosser, 1989: 57)

Konjonktürel dalgalanmaların kaynăg, teknoloji şokları olarak gösterilmektedir. Bununla birlikte konjonktürel dalgalanmaların kaynağı olarak, petrol şoklarını ve mali şokları gösteren çalışmalar da söz konusudur (Rebelo, 2005: 225-228) 


\subsection{Emek Piyasası Modeli}

Reel Konjonktür modelinin emek piyasası ile ilgili genişletilmiş modellerini inceleyebilmek için öncelikle Kydland ve Prescott'un temel Reel Konjonktür modelinde açıkladıkları emek piyasası olgusunu incelemek ve eleştiriler aracılı̆̆ıyla açıklayıcılığı artıran genişletilmiş emek piyasası modelini açılamak gerekmektedir. ${ }^{5}$

Reel Konjonktür teorisinin emek piyasası ile ilgili açıklamalarının konjonktür literatürüne önemli bir katkısı, kişi başı çalışılan saat değişimlerini içeren homojen işçilerdir. Kydland ve Prescott ABD ekonomisi verilerine göre çalış1lan saatlerdeki çeyrek dönemlik dalgalanmaların üçte birinin çalışılan saatteki değişmeden, geri kalan üçte ikisinin ise işçi sayısındaki değişimden kaynaklandığını ileri sürmüşlerdir. Bu bulgu, her ne kadar Hansen'in yalnızca istihdam değişimindeki hareketlerin dalgalanmayı oluşturduğu model ekonomide istihdamdaki dalgalanmaların ABD ekonomisindeki toplam dalgalanma ile benzer olduğu çalışmasına zemin hazırlasa da, aynı benzerlik Kydland ve Prescott'un " $u c ̧$ varsayım" olarak nitelendirdikleri yalnızca çalışan başına saat değişimindeki dalgalanma için de geçerlidir. Bu tartışma sonucunda Kydland ve Prescott her iki varsayımın da istihdamda meydana gelen hareketleri tam olarak ifade etmediğini iddia etmiştir. Dolayısıyla insanların işe girip çıkmalarının maliyetini hesaba katan ve emeği yarı-sabit bir girdi faktörü olarak gören, "kendilerine göre" değişken emek (labor hoarding) unsurunun modele dâhil etmişlerdir (Kydland and Prescott, 1991: 174-175).

Reel Konjonktür modellerinin reel ücret ile istihdam arasındaki ilişkiyi gerçeğe en yakın şekilde sergileyebilmesi için temel Reel Konjonktür modellerini geliştirme hedefine yönelik çalışmalar yapılmıştır.

Reel Konjonktür modellerinin emek piyasası analizleri ile ilgili bir başka çalışma, Hansen'in "Indivisible Labor and the Business Cycle" adlı çalışmasıdır. Hansen'in modelinde Kydland ve Prescott'un modelinden farklı olarak emek bölünmezdir. Yani boş zaman ikamesine gönülsüzlerdir. Modeldeki varsayım, insanların ya tüm zamanlarında çalıştıkları veya hiç çalışmadıkları gözlemine dayanmaktadır. Varsayılan ekonomide bireyler, çalıştıkları saatleri ayarlamak

\footnotetext{
${ }^{5}$ Konjonktür analizinde emek piyasasına yönelik açıklamalarda Reel Konjonktür teorisi için önemli bir alt başlık olan "değişken emek" unsuru tartışması, emek piyasası açıklamasında önemli bir role sahiptir. Reel Konjonktür temsilcilerinin "konjonktürel dalgalanmaya verimlilik değişiminin sebep olduğu" iddiasına karşın, "verimlilik değişiminin emek verimliliğinin bir yansıması olması nedeniyle dalgalanmanın asıl sebebinin verimlilik değișimi olmadığı" eleștirisi getirilmiștir. Buna göre çalışanlar, daralma döneminden genişleme dönemine geçiş sürecinde daha çok, genişlemeden daralmaya geçiş sürecinde ise daha az efor sarf etmektedir. Böylece konjonktürel dalgalanmanın asıl sebebi emeğin hareketi olmaktadır. Ancak emekteki hareket dalgalanma nedeni olarak kabul edildiğinde, emek talebi, yatırım gibi parasal faktörler öne çıkmaktadır. Dolayısıyla emek piyasası açıklamasında Reel konjonktür teorisini geliştirmeye yönelik modellerin dahil ettiği bir unsur olarak "değişken emek" unsuru, zımnen reel konjonktür teorisine parasal bir eleştiriyi ifade etmektedir Kydland ve Prescott, geçmişte konjonktür modellerinin emek girdisindeki değișimi ya işçi başına çalışılan saatteki değişime ya da işçi sayısındaki değişime atfettiklerini, ne var ki her iki değişimin de etkili olduğunu ifade etmişlerdir. Bu durumda Solow'un "dalgalanmaya etki eden teknoloji şokları" tezine uygun tahminlerde bulunan bir modelin dalgalanmaları açıklamada daha etkili olacağı savunulmuştur.
} 
yerine, bir teknoloji şoku karşısında işgücüne dâhil olurlar veya olmazlar. Hansen, bölünmez emek (indivisible labor) özelliğinin denge konjonktür modelleri için önemli bir rol üstlenebileceğini belirtmiştir (Hansen, 1985: 309-310).

Bir işçinin çalışması, ya sabit bir zaman miktarı ya da hiç çalışmamak şeklinde sınırlandırılınca, çalışma saatlerindeki değişim istihdamdaki değişimi oluşturmaktadır. $\mathrm{Bu}$ şartlar altında temsili ajan, ücret yüksek iken mümkün olduğu kadar fazla çalışmak istemektedir. Böylece ekonominin bütünü, bireysel ajanlar boş zamanın azalan marjinal faydasına sahip olsalar bile, sonsuz boş zaman ikamesi elastikiyetine sahip olduğu varsayılan bir ajan gibi hareket etmektedir. $\mathrm{Bu}$ tür bir emek arzı elastikiyeti açıklaması, mikro ve makro bulgular arasındaki farkları uzlaştırmakta ve Reel Konjonktür teorisine yöneltilen istihdam olgusunu açıklama konusundaki eleştirileri bertaraf etmektedir (Stadler, 1994: 1758-1759).

Temel Reel Konjonktür modelleri, verimlilik ile saat arasındaki korelasyonun gözlemlenenin aksine yüksek olduğunu göstermektedir. Hansen ve Wright hükümet ve bölünmez emek gibi bu korelasyonu azaltan unsurları modele dâhil etmişlerdir.

Çalı̧̧manın getirisi ve çalışılan saat sayısı makroekonomik modellerin başarısını ölçmek için önemli bir kriter olarak kabul edilmektedir. Reel Konjonktür modelleri, konjonktürel dalgalanmaların nedeni olarak dışsal şokları varsaymış ve ortalama verimlilik ile çalışılan saat arasındaki korelasyon 0.9 olarak elde edilmiştir. Ancak fiili durumda, bu korelasyon 0'a yakın olduğu için, Christiano ve Eichenbaum Reel Konjonktür yapısına hükümet harcamalarındaki stokastik hareketlerden doğan toplam talep şoklarını dahil etmiş ve ampirik sonuçlara göre, bu gelişmenin modelin ampirik performansını olumlu yönde değiştirdiği bulgusuna ulaşmışlardır (Christiano and Eichenbaum, 1992: 430).

Reel konjonktür modelinin emek piyasası açıklamasıyla ilgili bir başka çalışma da Hansen ve Wright tarafindan yapılmıştır. Hansen ve Wright, Reel Konjonktür modeline, hükümet harcamaları veya ev üretiminde meydana gelen şokun dahil edildiği durumda çalışılan saat ve verimlilik arasındaki korelasyonu azalttığı bulgusuna ulaşmışlardır (Hansen and Randall, 1992: 2-12).

Böylece standart Reel Konjonktür modellerinde görülen pozitif verimlilik ile çalışılan saat arasındaki korelasyon problemi önemli ölçüde azaltmaktadır. $\mathrm{Bu}$ tip bir model temel Reel Konjonktür modellerinin açıklayamadı̆̆ dinamiklerini açıklayabildiği için önem kazanmaktadır (Stadler, 1994: 1761)

Standart reel konjonktür modelinde emek piyasasını açıklamak amacıyla gerçekleştirilen yenilikler emek piyasasının stilize gerçekleri ile standart model arasındaki farklılıkları azaltmak için yapılmıştır. Bu bağlamda değişken emek, bölünmez emek gibi unsurların dahil edilme amacı standart modelin açıklamakta başarısız olduğu emek piyasası olgularını açıklama noktasında eleştirel gibi gözükse de, nihayetinde konjonktür literatürü içerisinde reel konjonktür teorisinin güncelliğini korumasını sağlamıştır. 


\subsection{Para Modeli}

Reel Konjonktür teorisinin parasal modelleri, finansal işlemler için gerekli olan zaman ve kaynakları değiştiren para arzı değişimlerini, yanlış fiyat algılamaları aracılığıyla çıktıyı etkileyen parasal şokları ve tüketim malları satın alımı üzerindeki nakit-avans kısıtlarını içermektedir.

Reel Konjonktür modeline para dahil edilerek, fiili durumda gözlemlenen para ve çıktı arasındaki pozitif korelasyon, modelde tahmin edilebilmektedir. Yine de finansal işlem teknolojisini veya nakit-avans kısıtını modele dahil etmek, Reel Konjonktür modelinin parasal olguları açıklayabilmesine çok fazla olanak sağlamamıştır. Çünkü paranın çıktıyı önemli ölçüde etkileyebilmesi, Walrasyen paradigmadan ayrılıp, ekonomide bazı nominal katılıklara izin verilmesini gerektirmektedir. Bütün iktisadi ajanların tüketim malları için nakit avans kısıtıyla karşı karşıya olduğu ve parasal ücretlerin bir veya daha fazla dönem için piyasaların temizlendiği durumdaki ücrete eşit olacak şekilde önceden ayarlandığ bir ekonomi varsayıldığında, para arzında beklenmeyen hareketler nispi ücretleri değiştirecektir (Stadler, 1994: 1763-1764). Bu durumda model gözlemlenen bazı gerçeklerle uyum sağlasa da paranın yansızlığı varsayımı terk edilmiş olacaktır.

Long ve Plosser, denge Reel Konjonktür modellerinin konjonktürel dalgalanmaya benzer davranışlar sergileyebilme yeteneğine rağmen bu modellere reel faktörler dışında parasal aksaklıklar gibi faktörlerin de dâhil edilmesinin önemli olduğunu ifade etseler de (Long and Plosser, 1983: 68 ) daha sonra bu görüşü "reel dalgalanmalar anlaşılmadan, bir varsayımın paraya önemli bir rol atfetmesi kolay değildir" (King, Plosser and Rebelo, 1988: 196) ifadesiyle bir şarta bağlamışlardır.

\subsection{Hükümet Modeli}

Kamu sektörünü içeren Reel Konjonktür modelleri, hükümet harcamalarının çıktıdaki dalgalanmalar üzerindeki etkisini incelemektedir. $\mathrm{Bu}$ modellerin uzun dönem politika değerlendirmeleri, neoklasik büyüme modeli ile tutarlıdır. Çünkü, reel konjonktür modelleri, temelde neoklasik büyüme modelinin uzantısıdır. Reel konjonktür modelleri, alternatif politikaların refah maliyetini değerlendirmede kullanılabilse de, bu modellerde heterojen ajanın, dolayısıyla gelir ve zenginliğin dağılımının bulunmaması, piyasa gücünün, işlem maliyetlerinin, dışsallıkların ve kamu mallarının yokluğu, politika değerlendirmesinde makul bir araç olarak kabul edilmesinin zor olduğunu göstermektedir. Temsili ajan varsayımı, bazı araştırmacılar tarafından bu modellerin güvenilirliğini zedeleyen unsur olarak görülmektedir (Stadler, 1994: 1764).

\subsection{Açık Ekonomi Modeli}

Açık ekonominin dâhil edildiği Reel Konjonktür modelleri, dış ticaret dengesinin konjonktürle ters yönde hareketi, dış ticaret dengesinin dış ticaret haddi ile pozitif korelasyona sahip olması ve tasarruf ile yatırımın açık ekonomilerde pozitif korelasyona sahip olması gibi stilize gerçekleri açıklamada başarılıdır. Bununla birlikte, açık ekonominin dâhil edildiği Reel Konjonktür modelleri, 
gözlemlenen iki stilize gerçeği açıklayamamaktadır. Ticari malları içeren Reel Konjonktür modelleri, her ülkenin farklı teknoloji şoklarını tecrübe ettiğini varsaymaktadır. Bu modellerde, iktisadi ajanlar uluslararası sermaye piyasalarına katılabilmekte, böylece tüketim ve yatırım yurtiçi çıktıya eşit olmakla kısıtlanmamaktadır. Reel Konjonktür modelleri, ülkeler arasındaki tüketim korelasyonunun çıtı korelasyonundan çok daha yüksek olduğunu tahmin etmektedir. Ancak fiili durum, bunun tam tersini göstermektedir. Bu durum, model yapısına ve parametre değerlerindeki değişime karşı dirençli olduğu için, miktar anomalisi olarak adlandırılmaktadır. Açık ekonominin dâhil edildiği Reel Konjonktür modellerinin açıklayamadığı ikinci stilize gerçek ise, dış ticaret hadlerinin Reel Konjonktür modellerinin tahmininden çok daha değişken ve kalıcı olmasıdır. Reel döviz kurlarındaki bu dalgalanma, fiyat anomalisi olarak adlandırılmaktadır. Miktar ve fiyat anomalisi durumlarını açıklayabilmek için ticari olmayan mallar, beğeni şokları, enerji fiyatı şokları, eksik varlık piyasaları ve para gibi birçok unsur Reel Konjonktür modellerine dâhil edilmiştir. Bu unsurlardan bazıları miktar anomalisini açıklamada başarılı olurken, miktar ve fiyat anomalisini birlikte açıklayabilme konusunda aynı başarı sergilenememiştir (Stadler, 1994: 1765)

\section{Reel Konjonktür Teorisinin Getirdiği Yenilikler}

Solow'un teknolojik değişimle çıktı arasındaki bağı Neo-klasik büyüme modelini kullanarak birleştiren ve çıtıyla birlikte toplam faktör verimliliğinde eş hareketin sergilendiği çalışmalarından (Solow, 1957: 312) hareketle inşa edilen Temel Reel Konjonktür modeli, Neoklasik sermaye birikimi modelinin geliştirilmesiyle oluşturulmuştur. Teorisyenler uzun dönem büyümeyi açıklayan teorinin, konjonktürel dalgalanmaları da açıklayabileceğini ileri sürmüşlerdir. $\mathrm{Bu}$ iddiaya göre, eğer Neoklasik büyüme modeline teknik ilerleme oranındaki stokastik dalgalanmalar dâhil edilirse, konjonktürel dalgalanma olgusu Amerika tarihinde gözlemlenen konjonktürle eşleştirilebilir. Bu iddialar nedeniyle Reel Konjonktür teorisi 1950'lerdeki Neoklasik büyüme modelinin gelişmiş şekli olarak ifade edilebilmektedir (Stadler, 1994: 1752-1753).

Reel Konjonktür teorisi, teknoloji şoklarının emek girdisinde genişlemeye imkan vermesi nedeniyle, geçici verimlilik şoklarının yer aldığ tek sektörlü temel Neoklasik büyüme modelinin yayılma mekanizmasını korumuş, bununla birlikte bu modelin sermaye birikimi mekanizmasının çıktı ve istihdamda makroekonomik verilerin gösterdiğine yakın bir korelasyon oluşturmaması nedeniyle mevcut yayılma mekanizmasını geliştirmiştir (King, Plosser and Rebelo, 1988: 197).

Reel Konjonktür Teorisi, iktisadi dalgalanmaların oluşma sürecini incelerken, itki ve yayılma mekanizmaları arasındaki farkı belirtmiştir. Buna göre itki mekanizması, öncü şokun bir değişkeni durağan durumdan saptırmasını, yayılma mekanizması ise, çeşitli güçlerin bahsi geçen öncü şokun etkilerini zaman içerisinde artırmasını ve durağan durumdan sapmayı kalıcı hale getirmesini ifade etmektedir (Snowdon ve Vane, 2012: 271).

Reel Konjonktür teorisi konjonktürel dalgalanma olgusunun açıklanmasını ampirik olarak tanımlaması ve bu tanımlamanın hesaplanabilir genel denge 
modelleri kurma yoluyla nicel olarak teorik hale getirilmesi ile makro iktisat için yeni bir metodoloji sunmuştur (Danthine and Donaldson, 1993: 1).

Reel Konjonktür teorisinin, konjonktürel dalgalanmayı açıklamada getirdiği bir başka yenilik kalibrasyon tekniği ile ilgilidir. Buna göre yeterli bir konjonktür teorisinin hem nicel hem de nitel açıdan açıklayıcı olması gerekmektedir. $\mathrm{Bu}$ teorik ihtiyacın sonucunda, konjonktür boyunca makro değişkenlerin hareketini tahmin etmeye ilaveten, bu dalgalanmaların ve değişkenler arası ilişkinin sayısal olarak açıklanması amacıyla kalibrasyon yöntemi oluşturulmuştur (Abel and Bernanke, 2001: 355).

Kalibrasyonda bir model ekonomi yazıldıktan sonra özel fonksiyonlar, sayısal olarak ifade edilerek daha çok özelleştirilir. Aynı şekilde, tüketici ve işçilerin davranışlarını tanımlamak için fonksiyonlara özel rakamlar atanır ve bu rakamlar genellikle makroekonomik veriden değil, üretim fonksiyonu veya birey ve ailelerin tasarruf davranışı hakkındaki önceden yapılmış çalışmalardan elde edilir. Daha sonra sayısal olarak belirlenmiş modelin, verimlilik şokları gibi tesadüfi şoklara maruz kaldığında nasıl davrandığı, bilgisayar ortamında oluşturulan ve gerçek makroekonomik veriye uyacak büyüklük ve kalıcılıkta şoklarla test edilir. $\mathrm{Bu}$ şoklar karşısında, bilgisayar birçok dönem boyunca modelin davranışını izler ve önemli makroekonomik değişkenlerin davranışını bildirir. $\mathrm{Bu}$ simülasyondan elde edilen sonuçlar, modelin gerçeğe ne kadar uyduğunu belirlemek için gerçek ekonomiyle karşılaştırılır (Abel and Bernanke, 2001: 355$358)$.

Reel Konjonktür analizinde kullanılan kalibrasyon yönteminin tanımlayıcı özelliklerinden biri, modelin parametrelerinin tahmini değil, ekonominin uzun dönem denge durumundan yola çıkılarak belirlenmiş olmasıdır. Bazı Reel Konjonktür çalışmalarında, kalibre yönteminden ziyade tahmin yöntemi kullanılsa da, Kydland ve Prescott kalibrasyon yöntemini bilimsel bir yöntem olarak tanımlarken; Hoover da, kalibrasyon yaklaşımını felsefi olarak övmüştür. Buna rağmen, kalibrasyon yöntemini kullanan Reel Konjonktür modelleri, yalnızca Amerikan verisine yakın veriye sahip ekonomilerde gerçek veriyle uyumlu sonuçlara ulaşıldığ şeklinde eleştirilmiş̧tir (Hartley, Salyer and Sheffrin, 1997: 12).

Reel Konjonktür teorisi, iktisadi dalgalanmanın stilize gerçekleri olarak adlandırılan, durgunluk ve refah dönemlerinde iktisadi değişkenlerin hareketiyle ilgili olarak diğer iktisat okullarının açıklamalarından farklılaşmıştır. Keynesyen, Monetarist ve Yeni Klasik iktisadın parasal aldanma hipotezi gereği fiyatların konjonktürle aynı yönde hareket edeceği tahminine karşılık, Kydland ve Prescott ABD ekonomisinde 1954-1989 yılları arasında bu kalıpta bir hareket görülmediğini belirtmiştir. Diğer iktisat okulları ile Reel Konjonktür teorisi arasında farklılık gösteren bir diğer stilize gerçek ise reel ücretin konjonktür boyunca hareketi ile ilgilidir. Bazı Yeni Klasik, Yeni Keynesyen ve Monetarist teoriler, reel ücrette sistematik bir hareket gözlemlenemeyeceğini iddia ederken, Kydland ve Prescott reel ücretin açık bir şekilde konjonktürle aynı yönde hareket ettiğini ileri sürmüştür (Snowdon ve Vane, 2012: 288-289).

Tipik bir konjonktür teorisi durgunluk evresi boyunca, tüketimin azalacağı ve boş zamanın artacağını ifade ederken, Reel Konjonktür teorisi, tüketim ve boş 
zamanın birlikte hareket ettiğini içerdiği için ilk bakışta problemli görünebilir. Reel Konjonktür teorisi, rasyonel bireylerin bu tercihinin tüketim ve boş zamanın normal mallar olduğu varsayımı altında beraber hareket sergilediğini ileri sürmektedir. Örneğin durgunluk döneminde boş zamanın fiyatı nispi olarak reel ücretin ve malların fiyatına göre daha fazla düșer. Bu nedenle, Reel Konjonktür teorisine göre, reel ücret konjonktürle aynı yönde hareket etmektedir (Mankiw, 1989: 82).

Reel Konjonktür teorisinin getirdiği bir başka yenilik, konjonktürün açıklanmasında uzun dönem-kısa dönem ayırımıyla ilgilidir. Konjonktürel dalgalanma ile büyüme arasında bir ayrım yapan görüş, konjonktürel dalgalanmanın ekonomiyi doğal orandan geçici olarak ayırarak kısa dönem dengesizliği ifade ettiğini, arz yanlı şokların da uzun dönem dengesinde etkisiz olduğunu ileri sürmektedir. $\mathrm{Bu}$ görüş makroekonomi alanında önemli bir tartışmaya yol açmıştır. Bu tartışma, son dönemde çıktı değişimini reel faktörlere atfeden, bütün dalgalanmaları aynı şokla açıklayan ve kısa dönem ile uzun dönem arasındaki dikotomiyi yok eden Reel Konjonktür teorisinin oluşmasına yol açmıştır (Shapiro and Watson, 1988: 111-112).

Yukarıda açıklanan kısa dönem-uzun dönem arasındaki ayrımın terk edilmesiyle ilgili olarak, Kydland ve Prescott'un konjonktürün reel faktörlerden etkilendiği şeklindeki yaklaşımı, büyüme ve iktisadi konjonktür olgularını entegre etmektedir. Çalışmalarında standart büyüme teorisinde olduğu gibi temsili bir sonsuz yaşayan hanehalkı varsayılmıştır. İstihdamdaki dalgalanmalar konjonktürel dalgalanma için merkezi bir öneme sahiptir. Neoklasik büyüme modeli, ekonomik zaman serileri dizisinin konjonktürel değişimini, reel çıktı değişimini açıklamak için değiştirmiştir. Ayrıca temsili tüketici, tüketimle birlikte boş zamanı da değerlendirmesine almaktadır. Standart Neoklasik büyüme modelinde yapılan önemli değişimlerden birisi de yeni sermaye malları inşa etmek için birden fazla dönemin gerekmesidir (Kydland and Prescott, 1982: 1345).

Kydland ve Prescott'un literatüre teknoloji şoklarının konjonktürel dalgalanmaların en önemli nedeni olduğu şeklindeki katkısıyla birlikte, diğer bir önemli katkısı politikaların zaman tutarsızlı̆̆ olarak adlandırılan yaklaşımla ilgilidir.

Firma ve hanehalkının karşı karşıya kaldığı maliye politikası kuralları, nispi fiyatları değiştirmekte ve ekonomik istikrar üzerinde önemli etkiye sahip olmaktadır. Vergi oranları optimal belirlendiği takdirde, vergi oranlarının konjonktürel dalgalanmaya uygun şekilde ayarlandığı politika, konjonktürel dalgalanmayı dikkate almadan uygulanan vergi oranı politikasına göre ekonomik istikrarı sağlamakta çok daha başarılıdır. Bunun için vergi oranları, konjonktürel dalgalanmayı oluşturan şoklara verilen yanıtlar olarak ayarlanmalıdır. Yatırımlar için geçici bir vergi indirimi, gelecekteki tüketimin maliyetini azaltır. Çünkü cari dönemde çalışma, boş zamana tercih edilir. Benzer şekilde ücret üzerindeki verginin geçici olarak değiştirilmesi, cari ve gelecekteki boş zamanın nispi fìyatını değiştirerek dönemler arası ikameye neden olmaktadır. Yine de vergi oranlarındaki değişim, dalgalanmaların şiddetine etki etse de, bireyler üzerindeki vergi yükünü artırmaktadır (Kydland and Prescott, 1980: 169-185). Dolayısıyla Kydland ve 
Prescott, vergi oranlarındaki değişimin dalgalanma üzerindeki etkisini kabul etseler de, maliye politikasını arzu edilmeyen bir durum olarak görmektedir.

Walsh'a göre konjonktür teorisi ile politik müdahale arasındaki ilişki konjonktür teorisinden politikaya doğrudur (Walsh, 1986: 4). $\mathrm{Bu}$ anlayış doğrultusunda iktisat okullarının konjonktür olgusu ile ilgili tartışmaları ve bu tartışmalar sonucu oluşan benzerlik ve farklılıklar, politik gündeme dair tartışmaları da içermektedir.

Reel konjonktür teorisinin getirdiği yenilikler şu şekilde özetlenebilir: Teknik ilerlemenin konjonktür analizine dahil edilmesi ve yayılma mekanizmasının geliştirilmesi hem konjonktür literatürü hem de Neoklasik büyüme modeli açısından bir yeniliği ifade etmektedir. Gerekli neoklasik araçların geliştirilmesi ve kalibrasyon tekniğinin uygulanması sayesinde nitel ve nicel açıklayıcılığa sahip konjonktür açıklamasında yeni bir metodoloji oluşturulmuştur. ABD ekonomisinde savaş sonrası dönemde gözlemlenen dalgalanmaların önemli bir kısmının teknolojik şoklar aracılığıyla açıklanabilmesi konusunda ampirik delillerin yeterliliği, makro ekonomi alanında çıktı, istihdam, yatırım ve tüketim gibi değişkenlerin konjonktürel hareketini teorik bir zemine oturtmak açısından önemli bir yeniliği ve gelişmeyi içermektedir. Konjonktür analizinde kısa-uzun dönem ayrımı yerine, büyüme ile konjonktürel dalgalanmanın dinamiklerinin aynı olduğu kabul edilerek, büyüme teorisi ile konjonktür teorisi arasında bir entegrasyon gerçekleştirilmiştir. Nominal değişkenlerden ziyade reel faktörlerin dalgalanma üzerindeki etkisine vurgu yapılmış, teknolojik gelişme oranındaki tesadüfî değişimin, dalgalanmaların asıl nedeni olduğu ifade edilmiştir. Buna göre teknoloji şokları, emeğin çalışma-boş zaman tercihine dayalı olarak ekonominin bütününe yayılmaktadır. Konjonktürel dalgalanma boyunca ekonomiye müdahale zararlı olmakta, ancak maliye politikası çalışma-boş zaman tercihine etkisi nedeniyle bu konuda istisna kabul edilmektedir.

\section{Reel Konjonktür Teorisinin Diğer Konjonktür Teorileriyle Karşılaştırılması: Farklıık ve Benzerlikler}

Ana akım iktisat okullarından biri olan Klasik iktisat okulu, iktisadi aktörlerin optimizasyonuna, nispi fiyatların arz ve talep dengesini ayarlamasına ve serbest piyasaya vurgu yaparken; diğer bir ana akım olan Keynesyen iktisat, iktisadi dalgalanmaların yalnızca genel dengenin inceliklerini araştırarak değil, piyasa başarısızlığını da hesaba katarak incelenmesi gerektiğini vurgulamıştır. Reel Konjonktür teorisi ise, Klasik iktisadi dalgalanma görüşünün yeni hali görünümündedir. Reel Konjonktür teorisi teknolojik değişim oranında büyük tesadüfi dalgalanmalar olduğunu, bu dalgalanmalara karşıllı bireylerin emek arzı ve tüketim kararlarını rasyonel şekilde değiştirdiklerini ve konjonktürel dalgalanmaların, mevcut üretim teknolojisindeki değişime verilen doğal ve optimum yanıtlar olduğunu varsaymaktadır (Mankiw, 1989: 79).

Long ve Plosser, model ekonominin sergilediği dalgalanmaların gözlemlenen konjonktürel dalgalanmaların önemli özelliklerini barındırması durumunda, bu dalgalanmaların Walrasyen ekonominin doğal oran patikasından refah azaltıcı sapmalar olarak görülemeyeceğini ifade etmişlerdir (Long and 
Plosser, 1983: 42 ). Bu ifade Reel Konjonktür teorisi ile Neoklasik teori arasındaki politikaların refahı azaltıcı etkisi konusundaki bağı göstermektedir.

King, Plosser ve Rebelo ortak çalışmalarında yaptıkları Reel Konjonktür analizlerinde iktisadi dalgalanmaların karakterinin inșasında Neoklasik faktörlerin rolünü sorgulamaktadır. Buna göre temel kavramlar, analitik yöntemler ve araştırmanın sınırları içerisindeki açık sorular göz önünde bulundurularak Reel Konjonktür araştırma programına bir giriş sağlanırken, temel Neoklasik sermaye birikimi modelinin dinamik yönlerine odaklanılmalıdır (King, Plosser and Rebelo, 1988: 195). Bir başka deyişle, Reel Konjonktür araştırmasının başlangıç soruları ve kavramları, Neoklasik teorinin altyapısına sahiptir, ancak bu altyapının geliştirilmesi için dinamik analiz şarttır.

Reel Konjonktür teorisi savunucuları, konjonktürel dalgalanmaların uzun dönem trendler etrafında geçici hareketler olduğuna dair iddialara itiraz etmiştir. $\mathrm{Bu}$ itirazın temeli, reel GSYIH gibi değişkenlerdeki dalgalanmaların geçici değil, kalıcı olduğu kabulüdür. Geleneksel görüşle Reel Konjonktür arasındaki en temel fark, ekonomik faaliyetteki değişimin nedenleri ile ilgili görüş farklılığından doğmaktadır. Keynesyen iktisatçılar iktisadi dalgalanmaların temel kaynăg 1 olarak toplam talepteki değişimlere vurgu yapmaktadır. Bu bağlamda, Keynesyen iktisatçılar konjonktürel dalgalanmaların önde gelen sebebi olarak, özel yatırım ve tüketim harcamalarındaki tesadüfi, geçici dalgalanmaları öne sürmektedir (Rush, 1987: 23).

Friedman, Lucas ve yapışkan fiyat modelini geliştirenler, konjonktürel dalgalanmanın geçiciliği-kalıcılığ $\breve{g}_{1}$ hususunda ittifak etmişlerdir. Fakat Reel Konjonktür temsilcilerinin konjonktürel dalgalanmanın büyüme trendi üzerindeki kalıcı etkisine dair ikna edici delillerinden dolayı, büyüme trendinden geçici konjonktürel ayr1lmalar olsa bile "ekonominin düz bir büyüme trendi boyunca hareket ettiğì" şeklindeki geleneksel görüş değişime uğramıştır (Hall, 2005: 133).

Her ne kadar Reel Konjonktür teorisinin Lucas'ın çalışmalarından etkilendiği belirtilse ve DeVroey, bu iki okulun Keynesyen teoriye karşı makro iktisat teorisinde devrim yaptığını ileri sürse de (DeVroey, 2009), Yeni Klasik okul ile Reel Konjonktür teorisi arasındaki farkl1likları belirtmek gerekmektedir. Bu farklılıklar Reel Konjonktür teorisi ile Yeni Klasik okul arasındaki bağın olduğunu kabul etmekle birlikte, bu iki okulun birbirini tekrar etmediğini göstermektedir.

Devroey'in tanımladığı devrimin ikinci safhası olan Reel Konjonktür teorisi, tam rekabet ekonomisi, denge disiplini, rasyonel beklentiler, stokastik dinamik çevre ve dönemler arası ikame kavramlarını içermesi bakımından, Lucas'ın çalışmalarıyla aynı kavramsal içeriğe sahiptir (DeVroey, 2009: 15). Bu benzerliğe rağmen parasal olmayan faktörlere ağırlık verilmesi, Reel Konjonktür teorisinin Lucas'ın çalışmalarından farklılığını göstermektedir.

Lucas ve Barro'nun çalışmalarıyla geliştirilen denge konjonktür araştırmaları ile Reel Konjonktür teorisi arasında iki önemli fark bulunmaktadır. Bunlardan birincisi, Reel Konjonktür teorisinin şokun etkilerinin zamanla yayılmasını ifade eden yayılma mekanizmasına, önceki denge konjonktür yaklaşımlarına nazaran daha fazla vurgu yapmasıdır. Diğer farklılık ise, Reel 
Konjonktür modellerinin parasal şokların aksine, reel şokların konjonktürü oluşturduğunu vurgulamasıdır (McCallum, 1989: 16).

$\mathrm{Bu}$ vurgunun arka planında, rasyonel beklentiler varsayımının kabulü gereği, sistematik genel ekonomik talep şoklarının, mal ve faktör piyasalarında esnek fiyat mekanizması aracılığıyla kendisini hemen fiyat değișimi şeklinde göstermesi sonucu reel değişkenleri etkilememesi yer almaktadır. Dolayısıyla sistematik talep şokları, konjonktüre etki etmeyen bir unsur olarak kabul edilir (Eroğlu, 1995: 26-27).

Reel Konjonktür modelleri, reel şoklara maruz ekonomilerde dalgalanmaların teknoloji ve verimlilikteki değişim gibi rassal değişimlere bireylerin optimum tepkilerinden doğduğunu göstermektedir. $\mathrm{Bu}$ modeller konjonktürel dalgalanmayı oluşturan neden açısından da sınıflandırıldığında, Yeni Klasik ve Yeni Keynesyen modellerde talep yanlı şoklar, Reel Konjonktür modellerinde ise arz yanlı şoklar ayırt edici unsur olmaktadır.

Reel Konjonktür modelleri, konjonktürel dalgalanmaların gösterdiği en önemli ampirik düzenlilikleri taklit edebilmektedir. Böylece Reel Konjonktür modelleri iktisadi faaliyetteki dalgalanmaların iktisadi ajanların rasyonel maksimize ediciler olduğu rekabetçi genel denge çevresiyle uyumlu olduğu için konjonktür literatürüne kayda değer bir katkı sağlamıştır. Bütün bu nedenlerden dolayı, koordinasyon başarısızlığı, fiyat yapışkanlığı, iyimserlik ve kötümserlik dalgaları, para politikası veya hükümet politikası gibi unsurlara konjonktürü açıklamak için ihtiyaç kalmamaktadır (Stadler, 1994: 1750-1751).

Reel Konjonktür modellerinin konjonktürel dalgalanmanın tek kaynağının parasal şoklar olmadığını hatırlatması, önemli bir katkıdır. Fakat yaygın kanaat, daha bütüncül bir konjonktür anlayışının hem parasal hem de reel konjonktür teorilerini içeren daha geniş bir teoriyle mümkün olduğu yönündedir (Walsh, 1986: 12). Şöyle ki 1970'li yıllardan itibaren ekonometrik yöntemdeki gözle görülür ilerleme, Neoklasik ekonometriyi konjonktür teorisine uygulama olanağını da sunmuş ve düşünülenin aksine teknoloji şoklarının, Amerikan savaş sonrası dönemdeki dalgalanmalarda önemli derecede etkili olduğu bulgusuna ulaşılmıştır. Ayrıca toplam dalgalanmaların teknoloji şoklarıyla açıklanmayan kısmının parasal şoklar nedeniyle gerçekleştiği düşünüldüğünde, para ve kredi unsurlarının yapıya adapte edilmesi ile ilgili çalışmalar ve genel denge yöntemlerinin ekonometrik olarak alternatif para ve kredi düzenlemeleriyle inşa edilecek bir parasal teori, gelecek için bir araştırma gündemi oluşturmaktadır (Kydland and Prescott, 1991: 176).

Konjonktür teorileri arasında reel veya parasal teoriler şeklinde mutlak bir seçim yapmak, kalıcı bir çözüm sağlayamamıştır. Reel Konjonktür teorisi, reel şokların birincil öneme sahip olduğu iddiasıyla parasal konjonktür modellerinin karşısında yer alsa da, bütüncül bir konjonktür teorisinin hem reel hem de parasal faktörleri hesaba katması gerektiği birçok iktisatçı tarafından vurgulanmıştır. Bunun en belirgin örneği temel Reel Konjonktür modelinin açıklamada yetersiz kaldığı konjonktürün stilize gerçeklerini açıklamak için para, hükümet, açık ekonomi ve emek piyasası gibi birçok yeni unsurun modele dâhil edilmesidir. 
Standart Reel Konjonktür modeline nominal ücret katılıkları dahil edildiğinde, parasal şokların çıktı üzerindeki etkisi artacak ve hem parasal hem de teknoloji şoklarının söz konusu olduğu reel konjonktür modellerinin performansını artıracaktır. Bazı nominal katılıkları içeren Reel Konjonktür modellerine, standart modelde görmezden gelinen bir unsuru dahil etmesi, ve Reel Konjonktür analizlerine bazı Keynesyen özellikleri dahil etmesi açısından önem arz etmektedir. Böylece, iki farklı iktisadi düşünce okulu arasındaki dikotomi birbirine bağlanmış ve Reel Konjonktür muhalifleri tarafindan gerekli görülen gelişmeler gerçekleştirilmiş olacaktır (Stadler, 1994: 1763). Nitekim Reel Konjonktür araştırmasında önemli etkisi olduğu kabul edilen Lucas'ın, Reel Konjonktür araştırmasına dair ifadesi, parasal karşıtı olan reel denge modellere odaklanmanın bir hata olmadığı, ancak melez bir modelin daha faydalı olabileceği şeklindedir (Rebelo, 2005: 218).

Reel Konjonktür teorisi, Klasik okul ile optimizasyon ilkesi ve serbest piyasaya bakışları açısından benzeşirken; Keynesyen teori ile piyasa başarısızlığ 1 ve devlet müdahalesi konularında farklılaşmaktadır. Reel Konjonktür teorisi, dalgalanmaların iktisadi aktörlerin optimum yanıtları olduğu, ve refah azaltıcı sapmalar olarak görülemeyeceği, ekonomiye müdahalenin zararlı olduğu, esnek fiyat mekanizmasının ve paranın yansızlı̆̆ının geçerli olduğu konularında büyük ölçüde Klasik okul geleneğinden ayrılmamıştır. Ancak parasal faktörlerin konjonktürel dalgalanma üzerindeki etkisinin reel faktörlere nispeten oldukça az öneme sahip olduğunu savunması açısından, Yeni Klasik okuldan farklılaşmıştır. Bununla birlikte Yeni Klasik ve Monetarist okulun çıktıda gözlemlenen dalgalanmaların geçici olduğu, konjonktürel dalgalanmaların belirli bir trend etrafinda hareket sergilediği görüşüne karşı; teknolojik şokla meydana gelen dalgalanmanın büyüme trendini yeni bir patikaya taşıdığı, dolayısıyla dalgalanmaların etkisinin kalıcı olduğu görüşünü ileri sürmüştür.

\section{Sonuç}

İktisat okulları birbirinden ayrı kompartımanlar gibi düşünüldüğünde teori ile pratik arasındaki bağın kurulması zorlaşmaktadır. Reel Konjonktür teorisi, Klasik iktisat okulu geleneğinin güncel hali olmakla birlikte, Klasik okulun mevcut iktisadi problemleri açıklamadaki yetersizliği nedeniyle, yeni paradigmalarla teorik açıklayıcılığı artırmıştır. İktisat literatüründe merkezi öneme sahip kriz, istikrar ve konjonktür gibi konularda yeni teklifler sunan Reel Konjonktür teorisi örneğinde varılan sonuç, tecrübe edilmiş konjonktürel dalgalanmaların büyük çoğunluğunu kendi paradigmalarıyla açıklaması ve düşünsel altyapısı 18. y.y.'da olan, fakat bu bağı pratiğe dair çözüm önerileriyle 20.y.y.'a taşıyan bir iktisat okulu olmasıdır.

Krizi açıklama gücü açısından makro iktisat alanında bir yeniliği ifade eden Reel Konjonktür Teorisi, dalgalanmaların açıklanmasında tahmin ve gözlem tutarlılığ 1 açısından önemli bir yer teşkil etmektedir. Kydland ve Prescott, teknoloji şoklarının toplam çıktı üzerindeki etkisini sağlam ampirik kanıtlarla temellendirirken; Long, Plosser, King ve Rebelo gibi iktisatçılar Reel Konjonktür teorisi ile ilgili yöntemsel eleştirilere karşı teorik olgunluğu sağlamak yolunda yeni çalışmalar yapmışlardır. 
Reel Konjonktür teorisi genel itibariyle teknolojide meydana gelen tesadüfi değişimin verimlilikte meydana getirdiği dalgalanmanın, çıktıdaki dalgalanmaya benzer özellikler taşıdığını ileri sürmektedir. Bu teorinin inşasında kabul ettiği varsayımlar, GSYİH'nın rassal yürüyüşe sahip olması ve GSYİH'nın yürüyüşünde meydana gelen şoklar karşısında kalıcı değişime uğraması, paranın reel değişkenleri etkilememesi ve teknoloji şoklarının çıktıdaki dalgalanmaların büyük kısmını açıklamasıdır. Bu varsayımların işleyişini sağlamak için de belirli şoklar karşısında nasıl davranacağı ölçülen temsili bir bireyin olduğu kabul edilmiştir. Temsili birey, bu şoklar karşısında belirli kısıtlara bağlı olarak optimum tepkiyi vermektedir. Dolayısıyla bu tepkiler, teknoloji şokları karşısında temsili bireyin verdiği optimum yanıtlardan oluşmaktadır. Bu ifade konjonktürel dalgalanmaya politik müdahale konusunda önemli bir yer teşkil etmektedir. Buna göre temsili bireyin davranışına müdahale etmenin sonucu, refah seviyesinin azalması şeklinde gerçekleşecektir.

$\mathrm{Bu}$ varsayımlardan hareketle oluşturulan modellerden elde edilen ampirik bulgular, özellikle 1950 ve sonrası Amerikan ekonomisinde gerçekleşen reel GSYIH dalgalanmalarının \%70'ini açıkladığ şeklindedir. $\mathrm{Bu}$ bulgu, Reel Konjonktür teorisi analizlerinde bütün dalgalanmaların teknoloji şoklarıyla açıklandığı şeklindeki iddiayı desteklememektedir. Aksine Kydland ve Prescott, konjonktürel dalgalanmaların reel şoklarla açıklanamadığ $\% 30$ ’luk bölüm için tutarlı bir parasal teoriye ihtiyaç olduğunu ifade etmiştir. Bu durum, ilerleyen dönemlerde genişletilmiş Reel Konjonktür modellerine emek, para, hükümet ve açık ekonomi gibi faktörlerin dâhil edilmesi ile neticelenmiştir.

Ekonomik hayata müdahale açısından paranın yansız olduğu varsayılmış olmasına rağmen, maliye politikasının çıktıyı etkileyebileceği ifade edilmiştir. Şöyle ki vergi oranlarındaki değişimle, kamu harcamalarını özel sektör ve kamu sektörü arasında yeniden tahsis ederek arz yanlı olarak belirlenen reel çıktı etkilenebilir. Maliye politikasının reel etkileri olduğu kabul edilse de, ekonomiye maliye politikası araçlarıyla müdahale edilmesi arzulanmamaktadır.

\section{Kaynakça}

Abel, Andrew B., Bernanke, Ben S. (2001), Macroeconomics, 4. bs., New York: Addison Wesley

Altuğ, Sumru. (2009), "Türkiye'de ve Yükselen Piyasa Ekonomilerinde İş Çevrimleri”, YTÜ Department of Economics Working Papers

Christiano, Lawrence J. Eichenbaum, Martin (1992), "Current Real Business Cycle Theories and Aggregate Labor Market Fluctuations", American Economic Review, 82(3), 430-450.

Danthine, Jean Pierre, Donaldson, John B. (1993), "Methodological and Empirical Issues in Real Business Cycle Theory", European Economic Review, 37(1), $1-35$. 
DeVroey, Michel, (2009), "New classical/real business cycle macroeconomics: The anatomy of a revolution", No 2009026, Discussion Papers (IRES Institut de Recherches Economiques et Sociales), Université catholique de Louvain, (Çevrimiçi) http://EconPapers.repec.org/RePEc:ctl:louvir:2009026, 16.11.2014

Eroğlu, Nadir, (1995), "Reel Konjonktür Teorisi”, M.Ü. İ.̇.B.F. Dergisi, 11(1-2), 25-34.

Haan, Wouter J., Ramey, Garey, Watson, Joel. (2000), "Job Destruction and Propagation of Shocks", The American Economic Review, 90(3), 482-498.

Hall, Robert E. (2005), "Separating Business Cycle From Other Fluctuations" Proceedings-Economic Policy Symposium - Jackson Hole, Federal Reserve Bank of Kansas City, issue August, p.133-179.

Hansen, Gary D. (1985), "Indivisible Labor and the Business Cycle", Journal of Monetary Economics, 16(3), 309-328.

Hansen, Gary D., Wright, Randall (1992), "The Labor Market in Real Business Cycle Theory," Federal Reserve Bank of Minneapolis Quarterly Review, Spring, p. 2-12.

Hartley, James E., Salyer, Kevin D. and Sheffrin, Steven M. (1997), "Calibration and Real Business Cycle Models: An Unorthodox Experiment" Journal of Macroeconomics, 19(1), 1-17.

Keova, Petya, (2000). "The Facts About Time-to-Build", IMF Working Paper, No:138.

King, Robert G., Plosser, Charles I. and Rebelo, Sergio T. (1988), "Production, Growth, and Business Cycles I: The Basic Neoclassical Model", Journal of Monetary Economics, 21(2): 195-232.

Kydland Finn E., Prescott, Edward C. (1996), "The Computational Experiment: An Econometric Tool", Journal of Economic Perspectives, 10(1), 69-86

Kydland, F., Prescott, E.C., (1991), "The Econometrics of the General Equilibrium Approach to Business Cycles", Scandinavian Journal of Economics, 93(2), 161-178.

Kydland, Finn E., Prescott, Edward C. (1982), "Time to Build and Aggregate Fluctuations," Econometrica 50(6), 1345-1369. November

Kydland, Finn, Prescott, Edward C. (1980), "A Competitive Theory of Fluctuations and the Feasibility and Desirability of Stabilization Policy", Rational Expectations and Economic Policy, Ed. by. Stanley Fischer, University of Chicago Press,

Kyun, Kim (1998), Equilibrium Business Cycle Theory in Historical Perspective: Historical Perspectives on Modern Economics, New York: Cambridge University Press.

Long, John B., Plosser, Charles, I.(1983). "Real Business Cycles", Journal of Political Economy, 91(1), 39-69. 
Yalova Sosyal Bilimler Dergisi

Mankiw, N. Gregory. (1989), "Real Business Cycles: A New Keynesian Perspective", Journal of Economic Perspectives, 3(3), 79-90.

McCallum, Bennet T. (1989), "Real Business Cycle Models", Modern Business Cycle Theory, ed.R.J.Barro, Cambridge, MA:Harvard University Press,

Nelson, Charles R., Plosser, Charles I. (1982), "Trends and Random Walks in Macroeconomic Time Series: Some New Evidence and Implications", Journal of Monetary Economics, 10(2), 139-162.

Özer, Mustafa ve Taban, Sami. (2006), Modern Konjonktür Teorileri, Geliştirilmiş İkinci Bask1, Ankara: Ekin Kitabevi

Plosser, Charles I. (1989), "Understanding Real Business Cycles". The Journal of Economic Perspectives, 3(3), 51-77.

Prescott, Edward C. (1986), "Theory Ahead of Business Cycle Measurement", Federal Reserve Bank of Minneapolis Quarterly Review, 10(4), 9-22.

Rush, Mark (1987), "Real Business Cycles", Federal Reserve Bank of Kansas City Economic Review, 87(2), 20-31.

Savaş, Vural, F. (1997), İktisatın Tarihi, İstanbul: Liberal Düşünce Topluluğu Yayınları

Rebelo, Sergio, (2005), "Real Business Cycle Models: Past, Present and Future", The Scandinavian Journal of Economics, 107(2), 217-238.

Shapiro, Matthew, and Watson, Mark.(1988), "Sources of Business Cycles Fluctuations", NBER Macroeconomics Annual, 3.

Snowdon B., Vane, H.R., (2012), Modern Makroekonomi: Temelleri, Gelişimi ve Bugünü, (B. Kablamac1) Ankara, Efil Yayınevi

Solow, Robert M. (1957), "Technical Change and the Aggregate Production Function", Review of Economics and Statistics, 39(3), 312-320.

Söderlind, Paul. (1994), "Cyclical Properties of a Real Business Cycle Model", Journal of Applied Econometrics, 9, 113-122.

Stadler, George W. (1994), "Real Business Cycles", Journal of Economics Literature, 32(4), 1750-1783.

Walsh C.E., (1986), "New Views of the Business Cycle: Has the Past Emphasis on Money Been Misplaced?". Federal Reserve Bank of Philadelphia Business Review, Jan-Feb, pp. 3-14.

Williamson S.D., (1996), "Real Business Cycle Research Comes of Age: A Review Essay", Journal of Monetary Economics, 38(1), 161-170. 